\title{
喫煙と下肢末梢動脈疾患に関する最近の知見
}

\author{
外田 洋孝 $*^{1}$, 廣岡 茂樹 $*^{1}$, 折田 博之 $*^{1}$, 若林 一郎 $*^{2}$ \\ *1 済生会山形済生病院心臟血管外科 \\ $*^{2}$ 兵庫医科大学環境予防医学
}

\section{Recent Knowledge of Smoking and Peripheral Arterial Disease in Lower Extremities}

\author{
Yoko SOTODA*1, Shigeki HIROOKA*1, Hiroyuki ORITA*1 and Ichiro WAKABAYASHI*2 \\ *1Department of Cardiovascular Surgery, Yamagata Saisei Hospital \\ *2Department of Environmental and Preventive Medicine, Hyogo College of Medicine
}

\begin{abstract}
Peripheral arterial disease (PAD) is an atherosclerotic obstructive disease of the arteries in lower extremities. Patients with PAD show high rates of mortality from coronary artery disease (CAD) and stroke. Smoking as well as diabetes is an important risk factor for PAD. A lesion of PAD in the lower extremities tends to be more proximal in smokers than in nonsmokers and to be more distal in patients with diabetes than in nondiabetics. By a systematic review, the odds ratio for PAD of smokers vs nonsmokers has been reported to be in the range of 1.7-7.4. Previous epidemiological studies suggest a stronger association of smoking with PAD than that with CAD. Nitric oxide (NO) is an important molecule suppressing the progression of atherosclerosis, but this function is compromised by smoking. Smoking decreases the bioactivity of NO and the expression level of NO synthase. In addition, smoking results in deteriorations of risk factors for atherosclerosis such as decreases in blood HDL (high-density lipoprotein) cholesterol and tissue plasminogen activator levels and increases in the levels of blood triglycerides, LDL (low-density lipoprotein) cholesterol, fibrinogen and the von Willebrand factor. Thus, smoking increases blood coagulability and deteriorates the blood lipid profile, resulting in thrombogenetic proneness and dyslipidemia. Smoking also increases the generation of atherogenic oxidized LDL in blood and decreases antiatherogenic prostacyclin production in the vascular endothelium. Smoking cessation is important for the prevention and therapy of PAD, and to this end, counseling by physicians and nicotine replacement therapy are useful and strongly recommended for patients with PAD.
\end{abstract}

Key words: PAD (末梢動脈疾患), smoking (哭煙), atherosclerosis (動脈硬化), cardiovascular disease (心血管疾患)， oxidative stress（酸化ストレス）

\section{1.はじめに}

下肢の末梢動脈疾患（Peripheral arterial disease, PAD） は動脈硬化を基盤として発症する下肢の血行障害であ り，その有病率は加齢とともに増加する。これまでわが 国では欧米諸国に比べて PADの有病率は低かったが,

受付 2014 年 12 月 9 日, 受理 2015 年 2 月 27 日

Reprint requests to: Ichiro WAKABAYASHI

Department of Environmental and Preventive Medicine, Hyogo College of Medicine, 1-1 Mukogawa-cho, Nishinomiya 663-8501, Japan

TEL: +81(798)45-6561, FAX: +81(798)45-6563

E-mail:wakabaya@hyo-med.ac.jp
最近の急速な高齢化と生活習慣の欧米化に伴い，今後 わが国でも PAD 患者の急増が予想される。PAD 発症の 危険因子として，加齢，哭煙，糖尿病，高血圧，脂質 代謝異常などがあげられるが，中でも喫煙はPAD 発症 とその病状悪化に強く関与する重要な危険因子であり, また禁煙によりPADの発症率が低下することが知られ ている。しかし，本邦での PAD の疫学についての知見 は限られて扣り，また喫煙とPADの病態生理について の報告も少ない。そこで，本稿では PAD に関する最近 の疫学的知見を紹介するとともに，喫煙による PAD 発 症の原因となる血管障害の分子レベルでのメカニズム 扣よび PAD 予防のために重要な禁煙対策について概説 する。 


\section{PAD の定義}

PAD 診療に打ける国際的なガイドラインの1つであ る TASC (The Trans-Atlantic Inter-Society Consensus Document on Management of Peripheral Arterial Disease) (1) によると，PAD はアテローム性動脈硬化症による下肢 動脈の閉塞性疾患と定義されて扤り，閉塞性疾患の原因 として稀である Buerger 病ならびに高安病や膠原病類縁 疾患などの炎症性血管疾患は除外されている。このこと から，TASC ガイドラインに抏いて PAD は下肢の閉塞 性動脈硬化症（arteriosclerosis obliterans, ASO）とほほ同 義として用いられている。一方 ACC/AHA (American College of Cardiology/American Heart Association) のガイ ドライン（2013 年）では, PAD は冠動脈以外の大動脈 ならびにその分枝動脈打よび下肢動脈に打ける動脈硬化 性, 血栓塞栓性の病変による狭窄・閉塞 - 瘤状病変と定 義されている(2)。さらに胸部大動脈, 頝動脈および椎 骨動脈，上肢動脈についてはエビデンスが少なく同ガイ ドラインから除外されているため, ACC/AHA ガイドラ インに颃けるPAD は下肢動脈 (lower extremity), 腎動 脈 (renal artery), 腸管膜動脈 (mesenteric artery), 腹部 大動脈（abdominal aorta）の閉塞性あるいは拡張性病変 に細分化されている。上記の概念が混在していることか ら，本邦ではPAD と ASO が同義語として取り扱われる 場合もあれば, ACC/AHA ガイドラインの様に lower extremity PAD として表現される場合もある。以上の様 にPADの定義については国際的に混乱がみられるが, 本稿では, PADをアテローム性動脈硬化症による下肢 動脈の閉塞性疾患と定義して用いることとする。

PAD は症状の有無により無症候性 PAD と症候性 PAD に大別され, 後者はさらに下肢虚血の程度により間歇性 跛行 (intermittent claudication, IC), 重症下肢虚血 (critical limb ischemia, CLI), 急性下肢虚血 (acute limb ischemia, ALI）に分類される。PADの簡易的かつ非侵襲的診断方 法として，上下肢動脈の収縮期血圧比（ankle-brachial systolic pressure index, ABI）の測定が用いられる。ABI が 0.9 以下の場合に PAD と診断され, ABI が 0.9 以下 0.7 以上で軽症, 0.7 未満 0.5 以上で中等症, 0.5 未満で重症 と分類される。ICの典型的な症状は運動時に出現する 下腿後面や大腿部の不快感と疼痛で, 数分の安静により 消失する。一方 CLI では安静時疼痛や虚血性潰瘍ある いは壊疽を伴い，発症後 10 年以内に下肢切断が必要と なる可能性は $80 \sim 95 \%$ と高率である。ALI では局所の プラークの破裂抢よび血栓による塞栓の結果，急激に下 肢血流が遮断されるため強い下肢の疼痛, 冷感, しびれ が出現し, 救肢のためには迅速な血行再建が必要である。

\section{PAD の疫学}

高齢化と生活習慣の変化にともない，先進国では冠動 脈疾患や脳血管疾患をはじめとする動脈硬化性疾患によ
る死亡率は増加の一途をたどっている。近年, アテロー ム性動脈硬化に起因する polyvascular disease のひとつと して PAD が注目されている。2013 年に報告されたPAD の有病率と危険因子に関するメ夕分析によると，世界中 でPADに罹患している人口は, 2000 年に 1.63 億人であっ たものが 2010 年には 2.02 億人と急増し, 10 年間に約 $24 \%$ もの増加を認めた (3)。

米国での The National Health and Nutrition Examination Survey（1999-2000 年）に扣いて実施された ABI を用い て診断されたPADの有病率は，40 歳以上 70 歳未満の 群では $4.3 \%$ であったのに対して，70 歳以上では $14.5 \%$ と高率であった（4）。また前述の 2000 年から 2010 年ま での期間に 34 力国で行われた研究をまとめたメタ分析 で, 29 歳から 99 歳の年齢を 5 歳毎に分類し, それぞれ の群に打けるPADの有病率を比較した結果, PADの有 病率は加齢とともに漸増すると報告されている。図 1 に 男女, 年齢および国の所得別にPAD の有病率を示す (3)。 このうち, 高所得国では男女に有病率の差はなかったが, 低中所得国では $85 \sim 89$ 歳未満の群で女性の有病率が男 性に比べて高く，その差は年齢とともに小さくなった。 60 〜 64 歳未満の女性では, 低中所得国での PAD 有病 率は高所得国に比べやや高く，それ以上の年齢では逆に 高所得国の方がやや高かった。一方，男性では高所得国 での PAD 有病率は低中所得国に比べて全年齢で高い傾 向にあった（3）。この文献の著者らは, 国民の所得の違 いによるPADの有病率への影響については, 低中所得 国では寿命が短く高齢の対象者数が不十分な場合がある 上，高所得国に比べて PAD 患者の予後が悪いことによ る PAD 有病率の過小評価を考慮する必要があると指摘 している。また，低中所得国では合併する冠動脈疾患に より早期に死亡する割合が，女性に比べて男性でより高 いため, 男性より女性での PAD 有病率が高くなってい る可能性がある。さらに, 低中所得国での PAD 有病率 については, 未知の危険因子が存在する可能性も指摘さ れている。

また，冠動脈疾患や脳血管疾患と異なり，先進国での PAD の有病率は男性と女性で㴗涪同程度であるが，80 歳以上の高齢者では男性よりむしろ女性での PAD 有病 率が高いとの報告も散見される（5）。PAD 患者では冠動 脈疾患ならびに脳血管疾患の合併頻度が高いことが知ら れている。非 PAD 群に比較したPAD 群の生命予後は悪 く，心脳血管疾患と関連した死亡の相対危険度（relative risk, RR）は $1.9 \sim 6.6$ とされ, PAD と心血管疾患, 特に 冠動脈疾患との間に強い関連性が存在する $(6)$ 。

本邦でのPADの有病率は $1.7 \sim 5.0 \%$ と報告されて招 り，欧米諸国でのPADの有病率に比較して低い傾向が 示されている (7-10)。40 歳から 93 歳の 2,402 人の男女 を対象とした九州・沖縄地方での横断研究では，ABI に より診断された PAD 患者数は, 2,402 人中 41 人 ( $1.71 \%)$ で，男性拈よび女性の PAD 有病率は，それぞれ $1.89 \%$, $1.73 \%$ であり，男女間で PAD 有病率に有意な差は認め 


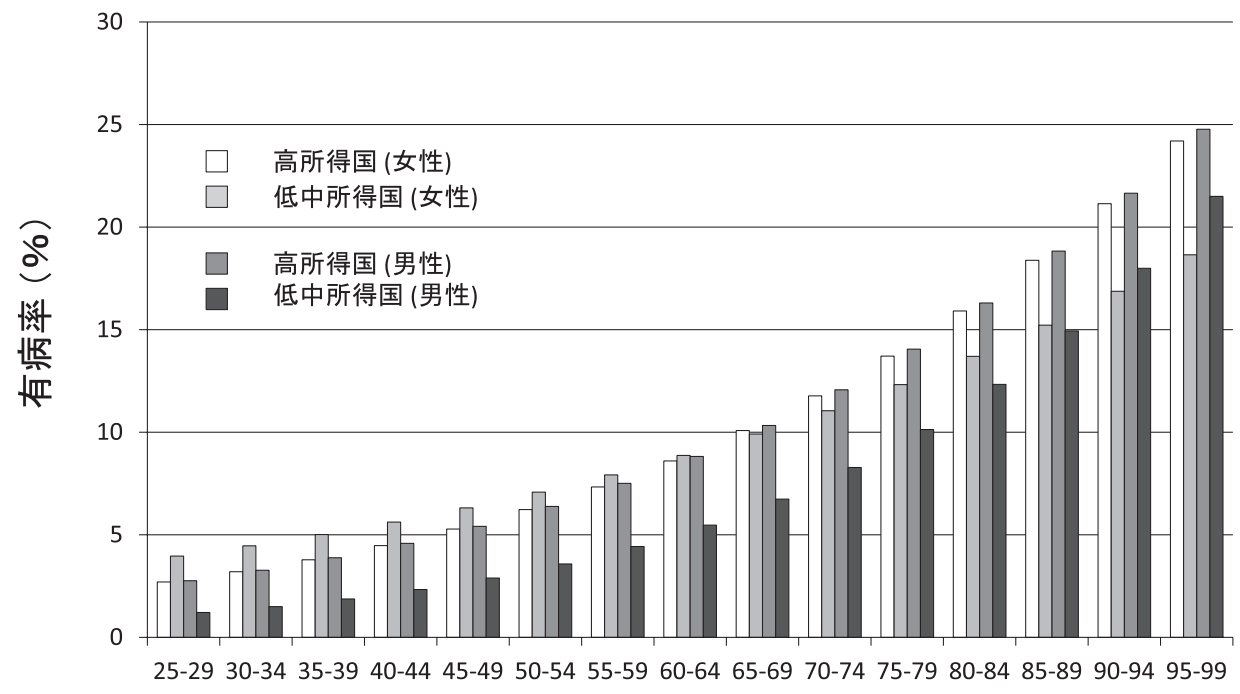

年齢(歳)

図 1 年齢, 性, および所得別の PAD 有病率。2000 年から 2010 年までに 34 力国で行われた研究をまとめたメ夕分析の結果を示す。 経済状況は地域により高所得国（オーストラリア，デンマーク，ドイッ，香港，日本，シンガポール，韓国，スペイン，スウェーデ ン，アメリカ）と低中所得国（ブラジル，中央アフリカ，中国，インド，メキシコ，コンゴ，南アフリカ，タイ）に分類した。文献 (3)より筆者らが作成した。

られなかった (7)。さらに対象者を年齢別に分類してそ れぞれの群に打けるPAD 有病率を評価した結果, 男女 ともに加齢とともにPAD の有病率が増加する傾向が認 められ, これまでの欧米からの報告と矛盾しない結果で あった（7）。また， 60 歳から 79 歳の日本人男性 1,219 人 を対象とした横断研究では, ABIにより診断された PAD の有病率は 5\%であった。同研究に扣いて PADの 危険因子について調査した結果, 非喫煙者と比較した現 契煙者に打ける PADのオッズ比（odds ratio, OR）は 3.8 （95\% 信頼区間 : confidence interval $(\mathrm{CI}), 1.1 \sim 13.0$ ) で あり, PADの危険要因として喫煙が強く関与している ことが示唆された $(8)$ 。

\section{PAD の危険因子}

PAD の危険因子として, 喫煙をはじめ加齢, 肥満, 高 血圧, 脂質代謝異常, 糖尿病などが知られている（表 1)。 中でも加齢, 喫煙, 糖尿病の PAD 発症に対する RRは, そ

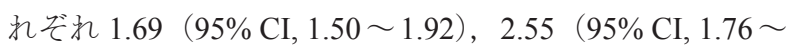
3.68)，4.05（95\% CI，2.78〜 5.90） と, 若年, 非契煙, 非糖尿病に対して有意に高く, これらの危険因子が PAD 発症に深く関与していると考えられる (11)。さら に, 遺伝的素因, 人種, 炎症性マ一カ一の上昇, 血液凝 固穴進状態, CKD (chronic kidney disease), 高ホモシス テイン血症なども PAD 発症の危険因子であるとされ (12), PAD 発症機序解明のために分子レベル执よび遺 伝子レベルでの研究が進められている。最近のゲノムワ イド関連解析の結果を用いたメ夕解析によると, 染色体 9p21 の CDKN2B (cyclin-dependent kinase inhibitor 2B) 遺伝子近傍の SNP（rs10757269）が ABI との間で最も強

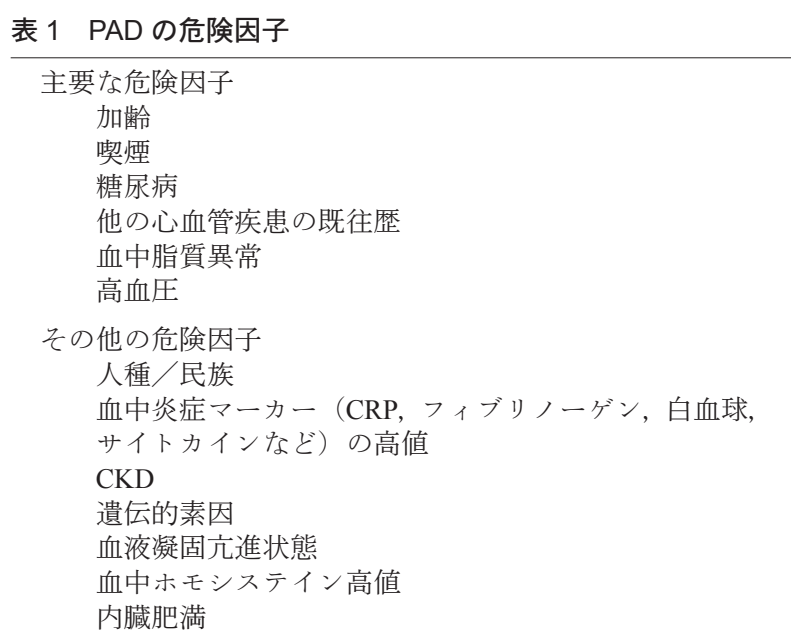

CRP, C-reactive protein; CKD, chronic kidney disease; PAD, peripheral arterial disease.

い関連性を示し，他の SNP と ABI および PAD との関係 は有意でなかったと報告されている(13)。

\section{PAD 発症のメカニズム}

動脈硬化症は，血管内膜の形態学的肥厚と中膜の弾力 性低下を引き起こす血管病変の総称であり，主に粥状硬 化症 (atherosclerosis), Monckeberg 中膜石灰化硬化症, 細動脈硬化症の 3 つ型に分類される。PAD は全身性 動脈硬化性疾患の一つであると考兄られて抏り，多くの 場合粥状硬化症に起因して発症する。一方, 透析症例で は Monckeberg 中膜石灰化硬化症が多く，糖尿病に打い ては細動脈硬化症に関連した糖尿病足病変の併存が知ら 
れて抎り, 中膜石灰化硬化症や細動脈硬化症はそれぞれ 透析症例や糖尿病に拈ける PAD の重症化に強く関与し ていると考古れている。PADではこれらのタイプの 動脈硬化症が混在して下肢血行障害を生じるが, 危険因 子により好発する病変部位が異なることが知られてい る。契煙や高血圧に関連したPAD では大動脈や大腿動 脈などの中枢性の血管病変が多いが, 糖尿病患者では鼠 径勒帯以遠, 特に膝下の末梢動脈に両側性, 多発性に生 じる病変が多い(14)。

PAD も他の動脈硬化性疾患と同様に血管内皮障害が 発症の引き金となることが知られている。血管内皮障害 は加歯令喫煙, 糖尿病, 高血圧などの種々の危険因子に より惹起される。内皮の障害により血管内皮上に沶いて VCAM-1 (vascular cell adhesion molecule-1) や ICAM-1 (intercellular adhesion molecule-1) などの接着因子が過剰 に発現する結果, 白血球の内皮細胞への接着と浸潤が惹 起され粥腫の形成に至る。また内皮障害では, 内皮型 一酸化窒素合成酵素 (endothelial nitric oxide synthase, eNOS）の発現とその活性が低下するが，その結果とし て内皮由来の一酸化窒素 (nitric ixide, NO) の産生量が 減少するため, 内皮依存性血管弛緩反応が減弱し虚血の 原因となる $(15,16)$ 。

さらに糖尿病では，血管内皮細胞におけるエンドセリ ン -1（endothelin-1, ET-1）やアンギオテンシン - II (angiotensin II, AT II）の産生増加が引き起こされる。これらの血 管作動物質はそれぞれ ET-A 受容体およびAT1受容体を 介して，血管収縮作用を示すとともに平滑筋細胞の増殖 を促進し, 動脈硬化症の発症や進行に関与している(17)。

動脈硬化巣に抏いて血管平滑筋細胞は収縮型から合成 型へ形質転換し, 中膜から内膜へ遊走し増殖する。合成 型血管平滑筋はコラーゲンを分泌し脂肪線条の表面に線 維被膜（fibrin cap）を形成することによりプラークの安 定化に関与している。種々の危険因子への曝露によって 血管平滑筋細胞の機能障害が生じると, アポトーシスに より動脈硬化巣に打洫管平滑筇細胞数が減少し, さ らに血管平滑筋でのコラーゲンの de novo 産生能が低下 する。またコラーゲンの破壞を促進する matrix metalloprotease (MMP) が増加する結果, プラークが不安定化 しプラーク破裂が生じやすくなることが知られている $(16,17)$ 。

血小板に打いても糖尿病をはじめとする動脈硬化症の 危険因子の影響により，DAG-PKC（diacylglycerol-potein kinase C）活性の亢進や血小板由来 NO の産生低下など が生じる。これらの機序を介して血小板内の $\mathrm{Ca}^{2+}$ 濃度 の恒常性に異常をきたす結果, 血小板の変形や凝集能立 進, トロンボキサン $\mathrm{A}_{2}$ の分泌増加などの異常が惹起さ れる。さらに, 糖尿病では血小板表面の GpIb と GpIIb/ IIIaの発現が増加して抢り, von Willebrand foctor（vWF） を介した血小板のコラーゲンへの結合とその後のフィブ リノーゲンとの結合が立進する。また，プロスタサイク リンおよびNOは血小板機能を抑制するが，糖尿病では
血管内皮に扣けるプロスタサイクリンやNO 産生の低下 により血小板凝集能はさらに六進し, 血栓形成が助長さ れる $(15,16)$ 。

上述のように，種々の危険因子により，下肢動脈の血 管内皮細胞掞よび血管平滑筋細胞, さらに血小板の機能 障害が引き起こされる結果 PAD が発症すると考えられ る。

\section{6. 喫煙と PAD の疫学}

喫煙は心血管疾患の重要な危険因子であり，特に PAD の発症と進行に深く関与する。スコットランドに 扣いて実施されたPAD 発症に対する喫煙の影響を検討 した前向き研究（Edinburgh Artery Study）では，55 歳か ら 74 歳の男女 1,592 人を対象に 5 年間追跡したところ, PAD の発症率は $5.1 \%$ であった（18）。現妿煙者あるいは 前喫煙者の占める割合は，非 PAD 群では 30.7\% であっ たのに対して，PAD群では 53.1\% と現契煙者および以 前の契煙者の割合が有意に高かった。また，契煙量と $\mathrm{PAD}$ 発症率の関連を検討した結果，PAD 発症率は非喫 煙者（pack-year =0）での $2.6 \%$ に対して, 中等度喫煙者 $(0<$ pack-year $\leqq 25 ） て ゙ は 4.5 \%$ ，高度喫煙者（pack-year >25）に打いては 9.8\% と高く，契煙量と PAD 発症率の 間には明らかな用量一反応関係が認められた。非契煙者 に対する現契煙者に扣ける PAD 発症の RR は, 中等度 契煙者で $1.87 （ 95 \%$ CI, $0.91 〜 3.85 ）$ ，高度喫煙者で 3.94 (95\% CI, $2.04 \sim 7.62)$ であった。喫煙量と PAD 発症と の間の用量一反応関係に関しては，アイスランドで実施 された前向き研究からも同様の結果が報告されている (19)。それによると 34 歳から 80 歳までの男性を対象と して 19 年間追跡調査した結果, 非喫煙者に比較した現 哭煙者の PAD 発症の RR は，一日の契煙量が $1 \sim 14$ 本 の現契煙者で 2.6 であったのに対して, $15 〜 25$ 本では 7.7 $(\mathrm{p}<0.001)$ ，さらに 25 本以上では $10.2(\mathrm{p}<0.001)$ と契 煙量に依存して PAD 発症の RR は上昇したといら。

一方，前喫煙者でのPAD発症率に関しては非喫煙者に 比較して有意な差は報告されていない。40歳から78歳の 男女 2,327 人を対象として 7.2 年間追跡したオランダの研 究では，現契煙者に抢ける PAD発症の OR $4.3(95 \% \mathrm{CI}$, 1.9〜 10.3） と高かったが, 前喫煙者での OR は $1.4 （ 95 \%$ CI, 0.5 3.7） と有意でなかった（20）。前喫煙者で PAD 発症の OR が上昇しなかった原因として，契煙量や喫煙 期間あるいは禁煙後の期間などのばらつきが関与してい る可能性がある。

これまでに喫煙とPADに関する横断研究の結果は数多 く報告されているが，いずれの研究においても非契煙者 に比較して現契煙者では PAD 有病率が高いことが示さ れている。2004 年に報告された喫煙とPAD に関するメ 夕分析によると, 非喫煙者に比較した現契煙者に抢ける PAD の OR は $1.7 \sim 7.4$ で, その加重平均は 2.3 と報告さ れている(21)。スペインで実施された契煙開始年齢と 
PAD 発症について検討した横断研究ではおよそ10\%に あたる 573 人中 61 人に PAD を認め, そのらち 16 歳未 満で契煙を開始した症例は約 75\%を占めていた。また, 哭煙開始年齢が 16 歳未満の群に抢ける PAD の OR（契 煙開始年齢が 16 歳以降の群に対する）は $2.91 （ 95 \% \mathrm{CI}$, 1.15〜 4.15) であり, 契煙量を補正しても 16 歳以降に喫 煙を開始した群と比較して PAD 有病率は有意に高かっ たと報告されている(22)。

現哭煙者を対象として PADの危険因子について検討 した英国の症例対照研究の結果では, PAD 患者群では 対照群に比較して高血圧と脂質代謝異常症の有病率が有 意に高かった。一方，使用されたタバコの種類は約 75\% が企業製のタバコで， $15 \%$ が紙巻きタバコ，その他の パイプや葉巻はそれぞれ数\%のみであり, PAD 群と対 照群間で有意差を認めなかった。また，PAD群におけ る危険因子についてロジスティック回帰解析を行った結 果, 収縮期高血圧と高血圧の既往歴さらにアポリポ蛋白 B の高值が現契煙者に扣ける PAD の有意な危険因子で あったと報告されている(23)。

PAD の性差に関する疫学研究によると, 男性と同様 に女性に扣いても契煙はPAD 発症の有意な危険因子で あると報告されている。米国でのWomen Health Studyに おいて, 39,825 人の健常女性を対象として 12.7 年間にお よぶ追跡調査を施行した結果, 178 人にPAD が発症した （24）。喫煙習慣により非喫煙女性, 前喫煙女性, 現少量

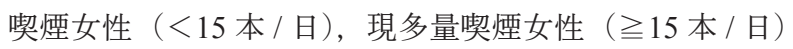
に分類し, 各群に拈けるPAD発症率を比較した結果, そ れぞれ $0.12 / 1,000$ 人年, $0.34 / 1,000$ 人年, $0.95 / 1,000$ 人年, $1.63 / 1,000$ 人年であり, 現契煙女性に执いて PAD 発症率 が有意に高い傾向が示された（24）。また女性のPADに 扣いても男性と同様に喫煙量と PAD 発症率の間には用 量一反応関係が認められたと報告されている（24）。

副流煙と PAD 発症の関連性について, 米国, 中国, スコットランドからの報告がある（25-27）。米国からの 報告では副流煙とPADの間に有意な関連は認められな かったとされるが (25), 中国扎よびスコットランドか らの報告では，副流煙はPADの有意な危険因子であり， 副流煙への曝露量や曝露期間と PAD との間に用量一反 応関係が認められたと報告されている $(26,27) 。$

韓国で施行された PAD への禁煙の影響を調査した横 断研究の結果では，喫煙者に拈ける非喫煙者に対する PAD の OR $4.3(95 \% \mathrm{CI}, 2.13$ ～8.66）であったのに 対して, 禁煙後 11 年から 20 年経過した場合の OR（現 喫煙者に対する）は $0.41 （ 95 \%$ CI, $0.19 〜 0.86 ）$ と低下 して扣り, 10 年以上の長期禁煙による PAD 発症のリス ク軽減の可能性が示された $(28)$ 。

\section{PAD および CAD 発症におよぼす 喫煙の影響の比較}

55 歳から 74 歳の 1,592 人の男女を対象とした Edinburgh
Artery Study では, PAD おょび冠動脈疾患（coronary artery disease, CAD）発症と喫煙との関連性の強さにつ いて, 横断研究扎よび 5 年間の追跡研究により比較検討 がなされている $(18,29)$ 。のらち横断研究では, PAD と CADの有病者数はそれぞれ 131 人，169人であり，現 契煙者の割合は, PAD群では44.5\%であったのに対して, CAD 群では 26.6\%であった (29)。このように PAD 群 に沶ける喫煙者の割合が CAD 群より有意に高かった。 さらに同研究では, 非契煙者と比較した現契煙者におけ る PAD の OR は， $5.09 （ 95 \% \mathrm{CI}, 2.97 ８ .72 ）$ と有意に 高かったのに対して，現契煙者に拈けるCADの ORは $1.72 （ 95 \%$ CI， 0.98～2.33）であり，非契煙者との間に 有意な差が認められなかったと報告されている(29)。

また, Edinburgh Artery Study の対象者を 5 年間追跡し た結果，PAD あるいはCADの発症率はそれぞれ 5.1\%, $11.1 \%$ であった（18）。PAD 発症群における生涯契煙量 は平均で 4.46 pack-years であったのに対して, CAD 発 症群では 3.41 pack-years であり, PAD 発症群において有 意に喫煙量が多かった。さらにPAD 発症群に扣ける現 喫煙者の割合は $53.1 \%$ で, CAD 発症群の $29.4 \%$ に比較 して有意に高かったと報告されており, 前述の横断研究 （29）の結果と矛盾しない結果であった。また，非喫煙 者と比較した多量喫煙者の PAD の RR は 3.94（95\% CI, 2.04 ～7.62）であったが, CADの RRは 1.66 (95\% CI, $1.07 \sim 2.58)$ と前者より低かった（18）。以上の結果より, 契煙は CAD に比較して PAD の発症により強く関与して いることが推測される。しかし, 冠動脈や下肢動脈といっ た血管床によって喫煙による血管障害の程度が異なるメ カニズムに関しては全く不明であり, 今後さらなる研究 が必要である。

\section{8. 喫煙による動脈硬化促進のメカニズム}

PAD の主な病態は下肢の動脈硬化であるが，喫煙は さまざまな機序を介して動脈硬化の進展を促進させる。 血管内皮細胞の eNOS により産生される NO は動脈硬化 の進展を抑制するが，契煙による動脈硬化促進作用の中 で重要な機序は，血管壁での NO 作用の減弱である。契 煙により活性酸素種（reactive oxygen species, ROS）の産 生が増加し， ROSにより血管内皮細胞が障害されると ともにNO の生物活性が低下する（15）。NOの減少は, 血管内皮依存性弛緩反応の減弱, 炎症性サイトカイン放 出の増加, 血小板凝集の増強をもたらす。その結果, 血 管平滑筋細胞の増殖は促進され, 動脈硬化が進行し, 虚 血が起こりやすくなる (30)。さらに喫煙者の血清や夕 バコ煙抽出物が構成型 NO 合成酵素の発現や活性を抑制 することが報告されている $(15,31)$ 。プロスタサイクリ ンはNO と同様に血管内皮細胞で産生され，動脈硬化の 進展を抑制するが，喫煙により血管内皮でのプロスタサ イクリン産生が低下することが知られている $(32,33)$ 。 組織因子（tissue factor, TF）は血液凝固の引き金とな 


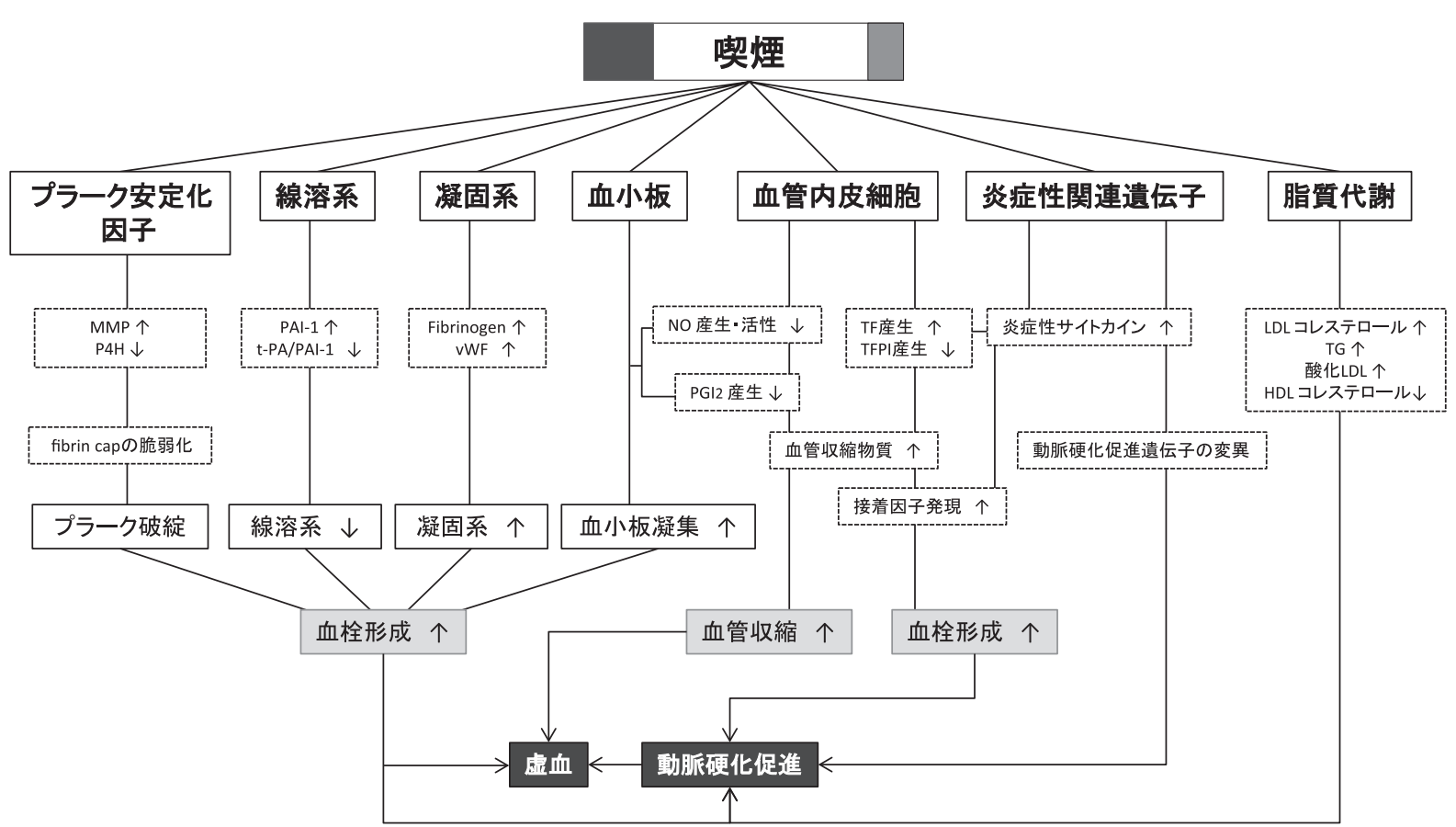

図 2 喫煙による動脈硬化促進のメカニズム。喫煙による血管内皮細胞，血小板，血液凝固系，脂質代謝などの異常を介する動脈硬 化促進のメカニズムを示す。NO, nitiric oxide; MMP, matrix metallo protease; P4H, prolyl-4-hydroxylase; PAI-1, plasminogen activator inhibitor-1; t-PA, tissue-plasminogen activator; $\mathrm{vWF}$, von Willebrand factor; $\mathrm{PGI}_{2}$, prostaglandin $\mathrm{I}_{2}$; TF, tissue factor; TFPI-1, tissue factor pathway inhibitor-1; LDL, low-density lipoprotein; HDL, high-density lipoprotein; TG, triglycerides.

る因子であり，通常は血管内皮細胞には存在しない。し かし，哭煙や種々の炎症性サイトカインによる刺激によ り, 内皮細胞に抢ける TFの産生が誘導されることが知 られている (34)。一方, 組織因子経路阻止因子（tissue factor pathway inhibitor-1, TFPI-1）は血管内皮細胞に捈い て産生され, 凝固活性を阻害するが, 喫煙により内皮細 胞からの TFPI-1 の産生は低下寸る (35)。このように喫 煙者では TF の増加と TFPI-1の減少により血液凝固能 が充進するとされ，これらの機序としても血管内皮障害 が関与していると考号れている。また, 契煙により動 脈硬化の危険因子が促進される。すなわち, 哭煙者では 血中 HDL コレステロールが低下し, 中性脂肪と LDL コ レステロールは増加する（15）。さらに，䒜煙による ROS の増加は酸化 LDL の増加をきたし，アテロームの 形成を促進させる（15）。契煙により血中フィブリノー ゲン, vWF, フィブリン D ダイマーが増加し, 組織プ ラスミノーゲン活性化因子が低下寸る結果, 血液凝固が 促進され，血栓形成が助長される(15)。さらに契煙に より，血管内皮細胞や血管平滑筋細胞，マクロファージ などに打いて MMPの産生が増加することが知られてい る（36）。また, prolyl-4-hydroxylase (P4H) は動脈壁の コラーゲンの代謝に寄与しているが，契煙の影響によっ て，血管内皮細胞に拈怕る $\mathrm{P} 4 \mathrm{H}$ の発現が低下すると報 告されている(37)。契煙による MMP の増加と $\mathrm{P} 4 \mathrm{H} の$ 減少は, プラーク表面の fibrin cap の菲薄化や脆弱性を 惹起することによりプラークの不安定化や破裂に関与し ていると考觉らる。喫煙による動脈硬化促進のメカニ
ズムを図 2 にまとめる。

一方, さまざまな疾患の遺伝子と哭煙との間の相互作 用が報告されているが，動脈硬化に関連する遺伝子と喫 煙との間の相互作用も知られている。例光ば, アポリポ 蛋白 $\mathrm{E}$ の $\varepsilon 4$ 遺伝子を有する喫煙者では非契煙者に比べ て心血管疾患のリスクが大きく増加する (38)。さらに 喫煙がエピジェネティクスに影響を及ぼし，DNAのメ チル化を介して動脈硬化の進展を修飾する可能性が最近 指摘されている。 protein-activated receptor-4（PAR4）は 血小板や血管内皮細胞および平滑筋細胞に発現している $\mathrm{G}$ 蛋白質共役受容体であり, 動脈硬化の病態に深く関与 するこれらの細胞の機能を調節しているが, PAR4の遺 伝子であるF2RL3 の契煙によるメチル化と冠動脈疾患 の予後との関連性が報告されている（39）。

\section{PAD の予防と禁煙指導}

前述のように喫煙は生体内の酸化ストレスを増加さ せ，血管内皮障害や脂質代謝異常，凝固系，線溶系の異 常などを惹起し，PADの発症や病状悪化に深く関与し ている。さらに，契煙者では偏食や喫煙による抗酸化物

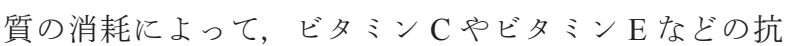
酸化ビタミンの血中濃度が有意に低下していることが知 られて打り，PADをはじめとする動脈硬化性疾患の発 症に影響を与えていると考えられる(18)。

PAD 発症に対する禁煙の効果を調査した横断研究の 結果によると, 10 年以上の長期禁煙群に抢ける PAD 発 


\section{表 2 PAD の予防対策}

\section{禁煙}

（1）全ての PAD 患者に対し禁煙指導を繰り返し実施するべきである。（Grade B）

(2) 全ての㚙煙患者は医師の指示に基づいた適切な禁煙指導やグループカウンセリング，ニコチン置換療法を受けるべきであ る。(Grade A)

（3）抗うつ薬の追加やニコチン置換療法で禁煙の成功率が上がる。（Grade A）

抗血小板療法

（1）全ての症候性 PAD 患者に対して心血管死亡率の軽減のために長期的な抗血小板剤の投与が推奨される。（Grade A）

(2) 間歇性跛行を有する PAD 患者に対する初期治療として cilostazol の投与は歩行距離の改善ならびに QOL の改善の点にお いて有効である。(Grade A)

降圧療法

（1）症候性 PAD 患者では 140/90 mmHg 未満の血圧管理が推奨される。さらに糖尿病あるいは腎機能障害を有する場合は 130/80 $\mathrm{mmHg}$ 未満の血圧管理が推奨される。(Grade A)

（2）Angiotensin converting enzyme（ACE）阻害剤はPAD 患者における心血管イベント回避の目的で，降压療法の導入薬剤と して推奨される。(Grade B)

脂質代謝異常の是正

(1) 全ての症候性 PAD 患者に抢ける血中 LDL-cholesterol の推奨值は $100 \mathrm{mg} / \mathrm{dl}$ 未満である。（Grade A）

（2）他の心血管疾患の既往歴を有するPAD 患者に抢ける血中 LDL-cholesterol の推奨值は $70 \mathrm{mg} / \mathrm{dl}$ 未満である。（Grade B)

（3）他の心血管疾患の既往歴を有さない無症候性 PAD 患者に打ける血中 LDL-cholesterol の推奨值は $100 \mathrm{mg} / \mathrm{dl}$ 未満である。 (Grade C)

糖尿病治療

（1）糖尿病を合併したPAD 患者の血糖管理は, HbA1c $<7.0 \%$ を目標としてコントロールするかあるいは可及的に HbAlc $<6.0 \%$ に近い值でコントロールすることが推奨される。(Grade C)

PAD 予防対策の TASC II ガイドラインに扔ける推奨レベルを下に示す。TASC II Working Group. J Vasc Surg（2007）。 Grade A：少なくとも 1 つのランダム化比較研究を含む，良質で一貫性を有する多数の論文に基づいた推奨事項; Grade B：良質なラ ンダム化比較研究には基づいていないが，良く管理された臨床研究の結果に基づいた推奨事項； Grade C : 専門家委員会の報告や意 見や権威者の臨床経験から得たエビデンスに基づいた推奨事項。

症の OR（現喫煙群に対する）は有意に低かったと報告 されて打り，長期禁煙によるPAD 発症のリスク軽減の 可能性が示されている (28)。また禁煙による PAD 患者 での間歇性跛行の症状軽減や，虚血性潰瘍の改善などの 効果が報告されて打り $(40,41)$, PAD 患者に打ける禁煙 の重要性が示唆されている。その他にPADの 2 次予防 として, 抗血小板療法や降圧療法, 血中脂質代謝異常の 是正などが有効であることが知られている $(1,2)$ 。抗血 小板療法は, cilostazol の投与による PAD 症状の改善と aspirin/acetylsalicylic acid（ASA）あるいは clopidogrel に よる心血管疾患イベント予防に伴う生命予後改善を目的 としている。一方, PADの 2 次予防に打ける高血糖治 療薬やインスリン抵抗性改善薬の効果に関しては, 現時 点では明らかなリスク軽減効果は報告されていない (42)。PADの予防対策を表 2 に示す。哭煙習慣を有す る PAD 患者に対する禁煙指導は, PADの治療ならびに 予防医学的観点から非常に重要であると考兄られる。確 実な禁煙を達成するためには, 医師の指示のもとに実施 されるカウンセリングやニコチン置換療法などを併用し た禁煙指導を長期間に繰り返し実施していくことが重要 である(43)。

\section{0. ま と め}

$\mathrm{PAD}$ はアテローム性動脈硬化症による全身性動脈硬 化性疾患の一つであり, PAD 患者では冠動脈疾患や脳 血管疾患の合併により心血管死亡率が高い。喫煙は酸化
ストレスの増大や炎症反応の立進によって，血管内皮細 胞をはじめとする細胞障害や血液凝固異常, 脂質代謝異 常などを惹起し PADの発症に強く関与している。禁煙 はPADの予防拈よび治療に有効であり，そのためには カウンセリングやニコチン置換療法などの医師による禁 煙指導が必要である。わが国では高齢化の進行や生活習 慣の欧米化により, PAD 有病率のさらなる増加が予想 される。PAD予防としての食事内容には低脂肪が含ま れるが (44), 生活習慣の欧米化により，わが国での脂 質エネルギー比率は，適正とされる基準レベルの $25 \%$ を平成以降では超えている(45)。また，運動不足は PAD のリスク要因である糖尿病, 高血圧, 血中脂質異 常の原因となる。PADの発症機序解明のための研究と エビデンスに基づいた危険因子改善による PAD および その合併症の予防法の確立が必要である。

\section{謝辞}

本研究は, 科学研究費補助金（課題番号 24390171） の助成を受けた。

利益相反なし

\section{文献}

(1) Norgren L, Hiatt WR, Dormandy JA, Nehler MR, Harris KA, Fowkes FG; TASC II Working Group. Inter-Society 
Consensus for the Management of Peripheral Arterial Disease (TASC II). J Vasc Surg 2007;45:Suppl S:S5-67.

(2) Anderson JL, Halperin JL, Albert NM, Bozkurt B, Brindis RG, Curtis LH, et al. Management of patients with peripheral artery disease (compilation of 2005 and 2011 ACCF/ AHA guideline recommendations): a report of the American College of Cardiology Foundation/American Heart Association Task Force on Practice Guidelines. Circulation 2013;127:1425-1443.

( 3 ) Fowkes FG, Rudan D, Rudan I, Aboyans V, Denenberg JO, McDermott MM, et al. Comparison of global estimates of prevalence and risk factors for peripheral artery disease in 2000 and 2010: a systematic review and analysis. Lancet 2013;382:1329-1340.

(4) Selvin E, Erlinger TP. Prevalence of and risk factors for peripheral arterial disease in the United States: results from the National Health and Nutrition Examination Survey, 1999-2000. Circulation 2004;110:738-743.

( 5 ) Vavra AK, Kibbe MR. Women and peripheral arterial disease. Womens Health 2009;5:669-683.

( 6 ) Golomb BA, Dang TT, Criqui MH. Peripheral arterial disease: morbidity and mortality implications. Circulation 2006;114:688-699.

( 7 ) Ohnishi H, Sawayama Y, Furusyo N, Maeda S, Tokunaga S, Hayashi J. Risk factors for and the prevalence of peripheral arterial disease and its relationship to carotid atherosclerosis: the Kyushu and Okinawa Population Study (KOPS). J Atheroscler Thromb 2010;17:751-758.

( 8 ) Cui R, Iso H, Yamagishi K, Tanigawa T, Imano H, Ohira T, et al. Ankle-arm blood pressure index and cardiovascular risk factors in elderly Japanese men. Hypertens Res 2003;26:377-382.

(9) Hozawa A, Ohmori K, Kuriyama S, Shimazu T, Niu K, Watando A, et al. C-reactive protein and peripheral artery disease among Japanese elderly: the Tsurugaya Project. Hypertens Res 2004;27:955-961.

(10) Ishida A, Miyagi M, Kinjo K, Ohya Y. Age- and sex-related effects on ankle-brachial index in a screened cohort of Japanese: the Okinawa Peripheral Arterial Disease Study (OPADS). Eur J Prev Cardiol 2012;21:712-718.

(11) Newman AB, Siscovick DS, Manolio TA, Polak J, Fried LP, Borhani NO, et al. Ankle-arm index as a marker of atherosclerosis in the Cardiovascular Health Study. Cardiovascular Heart Study (CHS) Collaborative Research Group. Circulation 1993;88:837-845.

(12) Sotoda Y, Wakabayashi I. Peripheral arterial disease. In: Wakabayashi I, Groschner K (ed), Interdisciplinary Concepts in Cardiovascular Health, Volume III, Cardiovascular Events. Wien: Springer-Verlag, 2013, 115-145.

(13) Murabito JM, White CC, Kavousi M, Sun YV, Feitosa MF, Nambi V, et al. Association between chromosome 9p21 variants and the ankle-brachial index identified by a meta-analysis of 21 genome-wide association studies. Circ Cardiovasc Genet 2012;5:100-112.

(14) Menzoian JO, LaMorte WW, Paniszyn CC, McBride KJ, Sidawy AN, LoGerfo FW, et al. Symptomatology and anatomic patterns of peripheral vascular disease: differing impact of smoking and diabetes. Ann Vasc Surg 1989;3: 224-228.

(15) Ambrose JA, Barua RS. The pathophysiology of cigarette smoking and cardiovascular disease: an update. J Am Coll Cardiol 2004;43:1731-1737.

(16) Barua RS, Ambrose JA. Mechanisms of coronary thrombosis in cigarette smoke exposure. Arterioscler Thromb Vasc Biol 2013;33:1460-1467.

(17) Beckman JA, Creager MA, Libby P. Diabetes and atherosclerosis: epidemiology, pathophysiology, and management. JAMA 2002;287:2570-2581.

(18) Price JF, Mowbray PI, Lee AJ, Rumley A, Lowe GD, Fowkes FG. Relationship between smoking and cardiovascular risk factors in the development of peripheral arterial disease and coronary artery disease: Edinburgh Artery Study. Eur Heart J 1999;20:344-353.

(19) Ingolfsson IO, Sigurdsson G, Sigvaldason H, Thorgeirsson G, Sigfusson N. A marked decline in the prevalence and incidence of intermittent claudication in Icelandic men 1968-1986: a strong relationship to smoking and serum cholesterol-the Reykjavik Study. J Clin Epidemiol 1994; 47:1237-1243.

(20) Hooi JD, Kester AD, Stoffers HE, Overdijk MM, van Ree JW, Knottnerus JA. Incidence of and risk factors for asymptomatic peripheral arterial occlusive disease: a longitudinal study. Am J Epidemiol 2001;153:666-672.

(21) Willigendael EM, Teijink JA, Bartelink ML, Kuiken BW, Boiten J, Moll FL, et al. Influence of smoking on incidence and prevalence of peripheral arterial disease. J Vasc Surg 2004;40:1158-1165.

(22) Planas A, Clará A, Marrugat J, Pou JM, Gasol A, de Moner $\mathrm{A}$, et al. Age at onset of smoking is an independent risk factor in peripheral artery disease development. J Vasc Surg 2002;35:506-509.

(23) Powell JT, Edwards RJ, Worrell PC, Franks PJ, Greenhalgh RM, Poulter NR. Risk factors associated with the development of peripheral arterial disease in smokers: a casecontrol study. Atherosclerosis 1997;129:41-48.

(24) Conen D, Everett BM, Kurth T, Creager MA, Buring JE, Ridker PM, et al. Smoking, smoking cessation and risk for symptomatic peripheral artery disease in women: a cohort study. Ann Intern Med 2011;154:719-726.

(25) Agarwal S. The association of active and passive smoking with peripheral arterial disease: results from NHANES 1999-2004. Angiology 2009;60:335-345.

(26) He Y, Lam TH, Jiang B, Wang J, Sai X, Fan L, et al. Passive smoking and risk of peripheral arterial disease and ischemic stroke in Chinese women who never smoked. Circulation 2008;118:1535-1540.

(27) Lu L, Mackay DF, Pell JP. Secondhand smoke exposure and intermittent claudication: a Scotland-wide study of 4231 non-smokers. Heart 2013;99:1342-1345.

(28) Lee YH, Shin MH, Kweon SS, Choi JS, Rhee JA, Ahn HR, et al. Cumulative smoking exposure, duration of smoking cessation, and peripheral arterial disease in middle-aged and older Korean men. BMC Public Health 2011;11:94.

(29) Leng GC, Lee AJ, Fowkes FG, Lowe GD, Housley E. The 
relationship between cigarette smoking and cardiovascular risk factors in peripheral arterial disease compared with ischaemic heart disease. The Edinburgh Artery Study. Eur Heart J 1995;16:1542-1548.

(30) Cai H, Harrison DG. Endothelial dysfunction in cardiovascular diseases: the role of oxidant stress. Circ Res 2000; 87:840-844.

(31) Zhang WZ, Venardos K, Chin-Dusting J, Kaye DM. Adverse effects of cigarette smoke on NO bioavailability: role of arginine metabolism and oxidative stress. Hypertension 2006;48:278-285.

(32) Busacca M, Balconi G, Pietra A, Vergara-Dauden M, de Gaetano G, Dejana E. Maternal smoking and prostacyclin production by cultured endothelial cells from umbilical arteries. Am J Obstet Gynecol 1984;148:1127-1130.

(33) Reinders JH, Brinkman HJ, van Mourik JA, de Groot PG. Cigarette smoke impairs endothelial cell prostacyclin production. Arteriosclerosis 1986;6:15-23.

(34) Matetzky S, Tani S, Kangavari S, Dimayuga P, Yano J, Xu $\mathrm{H}$, et al. Smoking increases tissue factor expression in atherosclerotic plaques: implications for plaque thrombogenicity. Circulation 2000;102:602-604.

(35) Barua RS, Ambrose JA, Saha DC, Eales-Reynolds LJ. Smoking is associated with altered endothelial-derived fibrinolytic and antithrombotic factors: an in vitro demonstration. Circulation 2002;106:905-908.

(36) Perlstein TS, Lee RT. Smoking, metalloproteinases, and vascular disease. Arterioscler Thromb Vasc Biol 2006;26: 250-256.

(37) Raveendran M, Senthil D, Utama B, Shen Y, Dudley D, Wang J, et al. Cigarette suppresses the expression of P4Halpha and vascular collagen production. Biochem Biophys Res Commun 2004;323:592-598.

(38) Talmud PJ, Stephens JW, Hawe E, Demissie S, Cupples LA, Hurel SJ, et al. The significant increase in cardiovascu- lar disease risk in APOEepsilon4 carriers is evident only in men who smoke: potential relationship between reduced antioxidant status and ApoE4. Ann Hum Genet 2005;69: 613-622.

(39) Breitling LP, Salzmann K, Rothenbacher D, Burwinkel B, Brenner H. Smoking, F2RL3 methylation, and prognosis in stable coronary heart disease. Eur Heart J 2012;33:28412848.

(40) Quick CR, Cotton LT. The measured effect of stopping smoking on intermittent claudication. Br J Surg 1982;69 Suppl:S24-26.

(41) Lambert MA, Belch JJ. Medical management of critical limb ischaemia: where do we stand today? J Intern Med 2013;274:295-307.

(42) Dormandy JA, Charbonnel B, Eckland DJ, Erdmann E, Massi-Benedetti M, Moules IK, Skene AM, Tan MH, Lefèbvre PJ, Murray GD, Standl E, Wilcox RG, Wilhelmsen L, Betteridge J, Birkeland K, Golay A, Heine RJ, Korányi L, Laakso M, Mokán M, Norkus A, Pirags V, Podar T, Scheen A, Scherbaum W, Schernthaner G, Schmitz O, Skrha J, Smith U, Taton J; PROactive investigators. Secondary prevention of macrovascular events in patients with type 2 diabetes in the PROactive Study (PROspective pioglitAzone Clinical Trial In macroVascular Events): a randomised controlled trial. Lancet 2005;366:1279-1289.

(43) Hennrikus D, Joseph AM, Lando HA, Duval S, Ukestad L, Kodl M, et al. Effectiveness of a smoking cessation program for peripheral artery disease patients: a randomized controlled trial. J Am Coll Cardiol 2010;56:2105-2112.

(44) Nosova EV, Conte MS, Grenon SM. Advancing beyond the "heart-healthy diet" for peripheral arterial disease. J Vasc Surg 2015;61:265-274.

（45）厚生労働統計協会. 国民衛生の動向・厚生の指標，61 巻 9 号, 2014. 